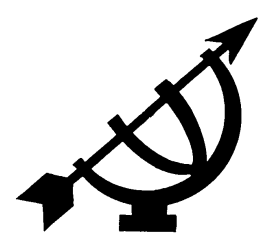

\title{
Discipling scholars and teaching teachers - towards a Biblically-based understanding of faculty development ${ }^{1}$
}

\author{
M. Elaine Botha \\ Professor of Philosophy (Emerita) \\ Redeemer University College \\ ANCASTER, Ontario \\ Canada \\ Senior Researcher \\ School of Philosophy \\ Potchefstroom Campus \\ North-West University \\ POTCHEFSTROOM \\ E-mail: ebotha@redeemer.on.ca
}

\begin{abstract}
Discipling scholars and teaching teachers - towards a Biblically-based understanding of faculty development
\end{abstract}

Faculty development is often a life-long process which does not bear fruit in one tenure-track term. Christian colleges and universities need to recognise that more factors contribute to faculty development than only those added to faculty development programmes on university campuses. Challenging university lecturers and academic teachers to change, even to cumulative change over the span of a lifetime, is what faculty development is all about. In order to achieve this goal we need, however, to develop an atmosphere and an ethos on campus that is conducive to such growth and change. Such an ethos should be rooted in an integral Biblical view of the world, but primarily in a world

1 This paper was delivered at a campus-based faculty development workshop of the Council for Christian Colleges and Universities (CCCU) in Denver, Colorado, USA during May 2001. The article is partially based on talks given at graduation ceremonies at Redeemer University College, Ancaster, Ontario, Canada and at The Kings College, Edmonton, Alberta Canada in 2000. Parts of the article is also based on the motivational speech for the OCSTA Convention in Ancaster, Ontario (2001). 
view that sees both professors, lecturers and students as gifted and unique beings called to be followers of Christ - also in an academic environment

\section{Opsomming}

\section{Akademici en dosente as volgelinge -'n Bybels-verantwoorde beskouing} oor die toerusting en vorming van dosente

Die vorming en ontwikkeling van akademiese personeel is 'n lewenslange proses en is nie slegs beperk tot die proeftydperk of eerste beroepsjare van dosente nie. Christelike instellings moet ook bewus wees van die feit dat daar veel meer faktore is wat' $n$ invloed uitoefen op die ontwikkeling van akademiese personeel as slegs daardie programme wat spesifiek gerig is op dosente-ontwikkeling. Universiteite en kolleges werk dus mee aan die ekologie van dosentevorming dwarsdeur die beroepsloopbaan van dosente. In personeelontwikkelingsprogramme behoort dosente voor die uitdaging van 'n leeftydlange kumulatiewe verandering geplaas te word. Die atmosfeer en etos op 'n kampus dra dan ook grotendeels by tot dergelike ontwikkeling en verandering. So 'n etos moet gewortel wees in 'n integraal Bybelse wêreldbeskouing wat sowel studente en dosente sien as unieke en begaafde geroepenes wat God moet dien ook in 'n akademiese omgewing.

\section{About the making of disciples}

Christian education is one of the ways in which followers of Christ are called to bring the "good news" to young people. This process of instruction should be applied in such a way that people become discipled - disciplined followers of our Lord in a world where bad news seems to dominate. This approach poses a challenge to all teachers at a tertiary level, mainly because few have been exposed to thorough reflection on what this challenge requires in terms of academic and personal development. Supplementing the requirement an advanced degree and a commitment to the Christian faith with a developmental programme aiming at the introduction of some basic insights in the "integration" of faith and learning has proven not to be adequate. Considering how we can equip teachers and researchers who are called to guide young people into disciplined discipleship in the transition from one generation to the next is what we need to reflect upon. This article aims to make a contribution to such a reflection.

All Christian academics are called to be Christ's disciples and to make disciples of a new generation - that is the inherent meaning of the purpose formulated as "discipling scholars and teaching teachers". The aim of such an approach implies trying to understand 
what Scripture reveals concerning the calling of lecturer and scholar to make disciples - i.e. followers of Christ - of all men and to disciple the young so that they come to know the Lord. Such a point of departure requires staying as closely as possible to the Biblical basics. An emphasis on Biblical basics is sometimes called "theology", but theology does not entail a discipline that should prescribe what the views and understanding of faculty development ${ }^{2}$ (the development of academic teaching and research staff at tertiary institutions) ought to be. When using the word "theology" in this article, I attempt to accommodate views that generally indicate the perspective of the Bible or faith on most other matters. I, however, believe that theology is a theoretical discipline which is as much bound to the directives of Scripture as are other disciplines. Both the disciplines of theology, philosophy and other disciplines thus need to listen carefully to what God says concerning His good creation and His plan for the redemption of a fallen creation (Wolters, 1985:57). These views should be informed by Scripture. The teaching mandate for Christ-centred academics comes very clearly to expression in the notion of being disciples and helping make others disciples, i.e. followers of Christ in and through teaching and of being teachers "... so that these young students as next generation would have a sense of Biblical direction and the Lord's presence as they struggle to work out shalom, despite sin constantly messing up their lives" (Seerveld, 2000:215). The ability to accomplish this aim does not happen without spiritual and intellectual growth. Such growth needs to be brought about by a dedicated programme to develop faculty (academic teaching and research staff) for their calling. This programme in turn requires a Biblical view of teacher and student and the community of believers of which they ought to form an integral part.

\section{God's diverse gifts to His community of believers}

Development assumes that faculty, i.e an institution's research and academic staff, already has potential that needs to be opened up and disclosed to come to full fruition. Development assumes the possibility of growth towards a goal that can be identified within the broad range of the vision of the general calling of all Christians. Development also implies growth towards the specific educational

2 The term "faculty development" is used in this article to refer to the processes of developing academic teaching and research staff at universities and colleges. The term "faculty", that is less common in South African English is used as a common denominator for academic teaching staff at a tertiary level. 
tasks that are part of the vision of the institution within which a faculty member is called to work. It further assumes movement in a positive direction towards more obedience and accountability in teaching, learning, scholarship, research and community service. Both academic institutions and lecturers need to have a clear vision of what the expectations are concerning growth in all these areas. A contract and/or faculty handbook in which this is spelled out clearly is a prerequisite for setting the parameters of expectations for growth. In such a contract the development of and growth in understanding of the integrality of faith and scholarship should form a constitutive part. The development of Christian perspectives in the various disciplines is no optional matter and contracts may not treat them as such.

It is generally accepted that there are three types of faculty development activities: the organisational, instructional and personal development of staff members. One needs to differentiate between organisational responsibilities for faculty development, and goals and objectives for personal and professional growth of faculty as teachers and researchers. In the case of research focused on professional growth, scholarship, teaching and community service form the core. Faculty development programmes should emerge from the vision and mission of the institution and not only from the "felt needs" of faculty. Such programmes need to address structure, funding, mandate, activities, publications, incentives, needs assessment and evaluation of professional development activities. They should also correlate very closely with what is happening in the personal life and growth of a faculty member. Faculty development programmes that do not accommodate the unique personal gifts and skills of their research and academic staff miss their target.

A Christian institution for tertiary education should incorporate in its view of faculty development the recognition of the diversity of Godgiven gifts to faculty. It is an injustice to assume that all members of the research and academic staff can develop in the same way and at the same tempo. We need to celebrate the diverse gifts that God has given an individual person and not attempt to force all faculty into the same mould. Given, there ought to be standards for teaching, for scholarship, for research, but these standards ought to allow for the rich diversity of gifts that people have and that have been entrusted to the staff of a tertiary institution to nurture and develop. In this respect one should not only think of academic and intellectual gifts. A specific dimension of development identified by Palmer (1998) should be kept in mind - the need to grow in selfknowledge and coming to terms with who you are. This process 
should be activated in order to be authentic and have integrity in teaching and research. If faculty stagnates in this area, whatever other "development" is suggested or follows is usually wide off the mark.

\section{Correlation between personal, spiritual and academic growth}

A very strong correlation can be discerned between personal growth, personality development and spirituality on the one hand, and academics' teaching and communication skills on the other hand. To the extent that one is able to recognise one's own weaknesses and failures and actively attempt to deal with them, to that extent one becomes more liberated as a person, more able to loosen up and teach with passion and compassion, more attuned to the needs of students and to God. This process can develop in both directions, but coming to terms with who you are before the Lord sets one free to love, serve and obey the Lord with joy and also convey this message to and liberate others. Understanding this freedom implies recognising that faculty development is often a lifelong process that does not bear fruit in one tenure-track term. Faculty development also implies recognising that more factors contribute to the overall faculty development than only those that we add to faculty development programmes on our campuses. Challenging academic and research staff to change, and even to cumulative change over the span of a life time is what faculty development is all about. We, however, need to develop an atmosphere and an ethos on campus that is conducive to such growth and change.

Some time ago Redeemer University College in Ancaster, Canada a small Liberal Arts and Sciences Christian college - embarked on a review of the core curriculum. Faculty were required to rethink what they thought the "profile" of an "ideal" Redeemer University College graduate would look like. It was a good exercise. It forced all involved to articulate the expectations they had of the educational processes and the outcomes they anticipated. This exercise also dictated the methodology and pedagogy required to achieve this "profile". It could be a very healthy spiritual exercise to attempt to define a similar profile for faculty at other Christian colleges and universities. Such a profile should be formulated within the broad parameters of the vision of the institution, but should also take into serious consideration the level of development where academic staff members are at when they embark on their academic career. An 
awareness of this aspect would help identify the type of outcomes or goals set to academic staff as individuals and as a community. Obviously these goals are intrinsically embedded in the vision of the institution. Requiring that departments reformulate their departmental goals on a regular basis in the light of the mission of a college or university is an important exercise that keeps the vision alive and mediates the process of "making the vision visible". The reasons for this is simple - teachers are required to teach "from the heart ..." (Palmer, 1988).

This prerequisite speaks to the inner state of the university teacher or, possibly in theological terms, this might be considered an incarnational task, i.e., embodying the heart. Development or renewal would be to help teachers achieve that incarnation. Not only the renewing of the mind, or renewing of teaching, but renewal of the person is at stake in this process. The goal to be achieved is integrity or coherence. When we speak of integrating faith and learning, faith and teaching, faith and scholarship, etcetera, we are really talking about helping persons achieving an integrity in their own life, where faith is integral to everything they do. Members of an academic staff need to be authentic teachers and researchers and this characteristic of authenticity should qualify all their activities. Such authenticity requires dealing with redemption and renewal of a world created by God - however, this present world may still be blemished, tarnished and broken by sin.

\section{Towards a Biblically-based understanding of faculty development}

As much as Christians want to regard redemption as their point of departure it is often the overwhelming and pervasive presence of both good and evil in and around us that confronts all of us on a daily basis. Academic staff and administrators struggle with the desperate need to heal and change that which is evil and broken in themselves and their surroundings and struggle to find ways to shalom or authenticity. Philip Yancey (2000:251) describes their move to Colorado - the "paradise" in his formulation - only to soon discover that the move did not actually change the circumstances:

The same cycle of goodness, fallenness and redemption applies to everything on this planet ... everything, in fact, that we humans touch gives off both the original scent of goodness and the foul odor of fallenness and requires the long, slow work of redemption. 
The realisation described in the above-mentioned quotation is a very simple but profound statement of what Scripture teaches. It sets out the parameters within which Christian institutions at tertiary level should think about their work with staff, students, faculty, administrators and the curriculum itself. These parameters also delineate the Biblical parameters within which the development of university teachers should be seen. In a nutshell these parameters are bound to the discovery of the contours of God's good creation, inter alia in

- the understanding of God's wonderful world which they are called to investigate and discover;

- the challenging and exciting task of education: teaching, learning, scholarship and research - the eyes of both teachers and of students should be opened to the fact that God reveals Himself to us in His creation and that reflection on a pedagogy inspired by a vision of God's revelation in His creation is an ongoing task that requires persistent attention.

Furthermore, the contours of God's creation should be discerned in the recognition of the many good and diverse gifts God gives to his people: administrators, academics and students.

In turn, the recognition of God's hand in creation will also provide insight into

- the understanding of the light of God's Word in Scripture on the curricular issues of the day;

- the corporate and institutional growth of understanding of the needs and goals of faculty development;

- the understanding of the nature of college and university education.

The sum total of the above-mentioned entails that Christian universities have a clear sense of what it is that they are called to accomplish in the process of education. 3

3 The title of the core curriculum review document of Calvin College is "Engagement in God's world. A statement of purpose for the core curriculum of Calvin College" (1997) Cf. also the earlier document of 1970 which expresses something of this dynamic call to be involved in the coming of the Kingdom of God. 
Recognising God's good creation means seeing university teachers as image bearers, created by God, gifted with manifold gifts for His service, endowed with the riches of God's call and blessings. Viewing university teachers in this light means recognising their God-given gifts and abilities in spite of their quirks and oddities, loving them in spite of them being "high maintenance faculty members" and "prima donnas". Perhaps this is one of the compelling reasons why faculty development programmes cannot only be generic in nature - evaluation processes should always also be geared to unwrap the individual gifts of the academic staff of an institution (Van Brummelen, 1986; 1988). These gifts are endowed for the sake of the new generation that is entrusted to the care of educational institutions and have to be used to disciple a new generation into joyful obedience to God and His call in the manifold rooms of His good creation. Clearly this view of God's creation leaves little room for otherworldliness and anti-intellectualism (Mouw, 1987:221).

Academic teachers - like all other believers - are called to a prophetic ministry: see-ing the invisible, the presence of the invisible God in His works, yet working at making His presence visible and tangible in the class room, in curricula, in lectures, in discussion groups, in course outlines in the many and diverse tasks that they are called to. Academic teachers are called to gently guide students in their care to "see" the world the way God has actually created it, what it is meant to be, albeit physical atoms, neurological processes or emotional states, communication, relationships, political policies or economic systems. Seerveld (2000) formulates this aim succinctly:

Psalm 78 speaks to us in our day of great societal complexity and myriad secular specializations that God's people need professional history-tellers and guides, that means, disciplined professing (-professional) story-tellers and searchers of God's ordinances, especially those laid down in God's glorious creation, to help orient the coming generation in understanding how to walk obediently before the Lord's face in faith, and hope and love.

The above-mentioned point of view entails that "creation" is not only an act that took place at the beginning of time; it does not only imply the beauty of God's wonderful gifts in nature, but actually is the world in which we live with all its diversity and splendour. "Creation" also imply the bounty of God's gifts to us in the wonder of innocent children - who are gifted with the ability to marvel and wonder, students who can unfold, blossom, grow and mature, and teachers and researchers with diverse gifts and abilities that can be used to 
magnify the Lord by magnifying the God-given creation so that young people get a glimpse of the Sovereign Lord and His resounding love for His world. Thus faculty development entails a way of looking at the world and seeing it as God's world - and not seeing this world as a secular place sold to sin and in need of shunning. Getting to know oneself as created by God and coming to see all of reality as God's world, is intimately related to knowing God in the full Biblical sense of the word.

For since the creation of the world His invisible attributes, His eternal power and divine nature, have been clearly seen, being understood through what has been made, so that they are without excuse (Rom. 1:20).

This perspective on the world and on creation leaves no room for dividing the world into the sphere of the sacred and the sphere of the secular or the sphere of the religious and that of the profane or the terrain of the "spiritual" and that of the worldly.

\section{Uncovering the roots of dualism and pluralism}

A Reformational Christian view emphasises the unity of human life in its religious concentration in Gods covenant with His people and world and in His Son Jesus Christ. Such a view precludes all forms of dualism that drives artificial wedges into and between different aspects of God's creation. There are clear links between a dualism which artificially separates the sacred and the secular, the resultant proclamation that the "secular" realm is neutral, and the wild pluralism that seems to be the inevitable result of a process of individualism and relativism. If we do not claim all dimensions of God's world as His, we give free reign to any possible point of view to claim ownership of it. A critique of wild pluralism will have to be based not only on its modernist moorings, but more specifically on the lack of recognition of God's stable and reliable order for His creation. This recognition emphasises the unity and thoroughly religious character of every single dimension of God's world and it acknowledges that God's creative and providential (structuring) Word upholds His creation and provides the orderly parameters within which humankind is called to live. The Reformational tradition is one that believes that Gods Word is adequate not only to all personal needs, but also to all the needs of a world filled too often with brokenness and sadness. University teachers should be grateful too that they can continue a tradition which proclaims that also teachers as part of the body of Christ are called to be coworkers of Christ and agents of renewal, We thus know that looking at the world in a certain way has consequences for the way we live 
our lives from day to day. We have become accustomed to talk about this view of the world as one in which we are convinced that God, the Creator is King of His creation in its totality. God reigns over the whole universe; He has the whole world in His hands. This is our Father's world and He has made us in His image - which does not only mean that we bear his stamp, that we are icons, but that we are called to reflect His glory, or who He is. Once we have come to understand that we live in a world that belongs to our Father, that we are legitimate heirs to His Kingdom and called to serve His rule, we take the cue for our lives from the basic direction that God's good creation gives us. Perhaps the secret of our witness is bound up with the fact that we are image bearers of our Lord icons of God who are called to proclaim His redemption and salvation in this world.

This is the witness that the first epistle of Peter is referring to. The purpose of the first epistle of Peter is to mobilise the resources of faith and action which will enable the Christian addressees to stand firm and persevere as the community of God in a society from which they are estranged. The context of the letter is one in which Christians are experiencing a situation of oppression, discrimination and persecution. They are aliens, strangers, sojourners. Peter writes to people involved in households where people are most probably oppressed by abuse of authority and he admonishes them to develop a life style that can respond in an adequate and Christian way to the oppression, suffering and discrimination. The ability to respond to these guidelines are based on the fact that the adressees have been given the new life in Jesus Christ. Although they are strangers and sojourners they have become part of a new people and are therefore equipped to exhibit this renewal in every dimension of their lives.

But you are the chosen race, the King's priests, the holy nation, God's own people, chosen to proclaim the wonderful acts of God, who called you out of darkness into his own marvelous light. At one time you were not Gods people, but now you are his people; at one time you did not know God's mercy, but now you have received his mercy (1 Pet. 2:9-10).

Rebecca Manley Pippert (1979) formulates this thought strikingly by saying that we are royalty walking the earth and therefore we may never forget that we are interacting with potential royalty. That is precisely what "discipling" is all about. What is, however, even more important is the fact that as heirs apparent we are called to be witnesses, agents and evidence of the King and His reign (Wolterstorff, 1984; 1987; 1989). 
Christian education should employ a world view, philosophy of education and educational theories, policies and practices that embody a perspectival view of the essential nature of reality that does justice to God's revelation in His creation. Furthermore Christian education should acknowledge the fact that Scripture and Jesus Christ, the Incarnate Word, re-directs our understanding of God's original revelation which was damaged and distorted by sin. This re-direction is not to be understood as the provision of detailed encyclopaedic statements about every possible subject matter but should rather be understood as a revelation of God's covenantal purpose with His creation and creatures. Our response to God's revelation in His world, His Son and His Word is our obedience and service to His all encompassing claim to human life. This approach comes to expression in our "way-of-seeing" the world, our selves and human life. Such a vision, such a view provides Christian educators with an understanding about things that really matter ... and in God's Kingdom all things really matter.

\section{Afraid to venture into the world?}

Students are often guided towards their entry into the world of ideas and ideologies by the example of the courage of the teacher to venture there. Students often learn more in the process of their educators' modelling the encounter with the world and what it offers, than what they would learn from reading books on their own. Often our inability to actually deal with the very real temptations of secular ideas bind them too. Faculty development should be aimed at discipling scholars and teaching teachers what it means to take each thought into captivity and obedience to Jesus Christ (2 Cor. 10:5).

My personal confidence as teacher teaching Ethics in apartheid South Africa in the early seventies was brutally shattered in 1976. As many other Christian teachers I was teaching subject matter without relating the abstract theories of textbooks to the concrete reality of discrimination and racial oppression which surrounded all of us at every turn. It was only when the revolt of elementary school children broke loose that many of us were suddenly forced to acknowledge that we were imparting bloodless, abstract theoretical ideas baptised by some Christian gloss without guiding students in the very real spiritual struggle that was taking place outside the walls of the campus. Only when we were empowered to venture into the fray of the political struggle, were we able to look over our shoulders to see students following our example. 
Similar struggles are taking place today in Christian circles about the reading of the Harry Potter series and "The passion of the Christ" by Mel Gibson. If academic teachers are afraid to venture into these discussions and to raise their prophetic voice or are afraid to set an example, they allow the weeds of unbelief to grow in parts of God's good creation, whereas they as teachers are called to claim the Lordship of Christ. In a Redeemer College faculty colloquium discussion on the task of Christians in business and economics an example of this issue arose. When confronted with the manifold unjust practices in the market-place and asked what a Christian scholar's attitude would be towards them, a faculty member argued that when Christians are called to participate in the market-place they should trust the processes of economic equilibrium in the market to determine prices. The market has a knack of stabilising itself, he argued. When challenged by the audience that often the forces of the market-place are determined by greedy and unwise human decisions that are not obediently seeking God's will for economic processes, another responded: then Christians have to withdraw from the market-place! Both these responses reveal a warped and distorted understanding of God's call not only to see God's world in the right perspective, but also to claim all of creation as His world.

Acknowledging God's magnificent creation as His world means appointing teaching and research staff who share this vision, but also mentoring and guiding them to the full understanding of what this realisation implies in teaching, curriculum development and research. This aim implies a task of polishing the lenses with which they see God's world, a task that should be pursued tenaciously, not giving up on challenging researchers and teachers to venture into new and challenging areas. It is this shared vision which ought to be the binding factor in an academic community, but this vision also requires the cultivation of community.

Sin has left its mark on every single dimension of human life and academic institutions. Academic staff and students are not exempt from this. We need a very realistic appraisal of the nature of sin and its devastating effects in human lives if we want to develop effective measures for faculty to grow and develop. Not only do we need to deal very decisively with this recognition in our own lives, but we need to sensitise students to this fact in the ideas they are confronted with and the way they see the world. The modelling of what a Christian community is all about is, however, equally important. Students often do not believe the content of our lectures 
when our relationships are so clearly contradictory to what we teach in the class room.

\section{Community and the culture of exhaustion}

Not being deeply conscious of how broken our world is, is unrealistic and foolish. We have all either experienced or seen others experience stress, tension, pressure. Who is not familiar with the constant refrain: There is just not enough time! Many campuses are characterised by a culture of exhaustion. There is also the intangible factor of the "institutional ethos or institutional environment" which either encourages or hinders personnel morale and development and can contribute to such a culture of exhaustion. The odd thing about this phenomenon is that it is to some extent self-perpetuating. Academics work too hard, feel they work too hard, feel guilty if they are not constantly busy or demonstrating that they are working too hard and after a while this attitude permeates the whole work ethos. Morale plunges and productivity suffers. No matter how many "wellness" programmes we launch, situations like these call for radical Biblical surgery.

Administrators and faculty are called to think carefully about the sources and origins of this malaise. Too many academics and administrators believe that they are called single-handedly to personally usher in God's Kingdom. Such a serious sense of calling is laudable, but needs to be tempered by the constant reminder that it is God who brings his Kingdom to fruition and who blesses the work of our hands. We also need to be sensitive to the need for rest and relaxation and renewal of faculty. Many colleges either do not have sabbatical arrangements or do not think faculty require them or perhaps just believe that they are too expensive. The Biblical custom of rest and renewal should be part and parcel of our lives and requires that we think very seriously about sabbatical programmes.

We also have to think carefully about the cultivation of Christian community and collegiality. In the secular atmosphere of competition that often pervades university campuses, the reality of Christian collegiality can be a fresh wind of witness and the power of renewal present in God's people. Why is it then that young, new, single and part-time staff members often complain about their isolation, their loneliness, their sense of not being supported and not being part of the community? God-given gifts are meant to be cultivated in community. They are given for the sake of the building up of God's people. God-given gifts are meant to demonstrate the rainbow 
colours of God's grace in this world. How often do we not limit these colours to only those that we have or cherish or prioritise. This understanding needs to permeate policies about which dimensions of the personal and or academic life of faculty are in need of development, views of subject matter to be taught, the curriculum, the sensitivity to community and the expectations we have about all of these.

Have you also at times been disillusioned with the inability of faculty including yourself to genuinely rejoice in the God-given gift of colleagues? How seldom do we encourage, support, rejoice with colleagues? How much do we embody the ministry of affirmation? Academic teachers model ways of living to their students, but a campus lacking in generosity, hospitality and charity and excelling in rigidity cultivates the same attitude towards life in the students entrusted to the teachers' care. The academic community itself must be a living witness to the possibility of renewal before it can undertake the task of renewing education or the wider world in which it is called to serve the Lord. Redemptive communities are called to redemptive education and renewal.

\section{Making the vision visible - a covenantal task}

Many Christian colleges and universities are challenged by the difficulty of attracting competent and qualified staff who share the vision of Christian scholarship and education. Deciding whether academics have adequate academic competence is not so difficult. A faculty handbook prescribes that academic staff members should have obtained a Ph.D. in their discipline (and in some disciplines at least the highest academic qualification required by the discipline, e.g. a Master of Fine Arts or Chartered Accountant Certificate). The difficulties experienced in finding competent academics who share the vision of Christian colleges and universities, however, pose a different challenge. This phenomenon forces us to look closer at what we mean with the phrase "sharing the vision." Christian teachers are confronted with a number of issues in this respect: There does not seem to be an abundance of applicants for most positions at Christian colleges and universities. Applicants who apply are fine, committed and devoted Christians and in many cases very competent academics, scholars and teachers, but seem not to be cognisant with the basics of a Reformational vision and tradition. Even when they are conversant with a Reformational vision they are not actually able to articulate this or to convey the intrinsic meaning of such a vision in their teaching. It is obvious that we need to develop remedial measures much along the already instituted by 
other institutions. For this purpose faculty development courses or sets of workshops and mentoring procedures that would assist new staff in their development as Christian teachers and scholars have been developed by a number of Christian institutions. As one sets out to do this, it soon becomes clear that teaching teachers to teach is not such a simple matter! How does one go about re-forming a mind that has already been highly academically formed? How does one gently nudge a colleague to grow in areas where Ph.D. training was not able to reach? It is clear that faculty development is an area that relates to deeper realms of maturity and growth than only that which can be acquired by means of academic and intellectual formation. The development of academic and research staff is embedded in the spiritual mind set and perspective of academics, one that has been formed by many forces: books read, lectures absorbed and the religious and academic traditions within which this formation took place. For many this change in mind set is something akin to a radical conversion. For most it is deeply embedded in the ongoing process of sanctification: of learning how to see more clearly the contours of God's sovereign ownership of His world and coming to understand His claims to allegiance and obedience in all realms of life.

Institutions and faculty members should come to an agreement with one another regarding the mission and world view of the institution. They should be partners in fulfilling the mission. This agreement requires some responsibility for the institution in developing the gifts for fulfilling that mission and the teaching and research staff's commitment to the task. This mission and vision also imply convincing both teachers and students that the vision of the school sets the direction in which one needs to move. Making this vision visible in the variety of dimensions of the life of the institution and more specifically the life and work of those entrusted with the calling to teach and to do research is one of the pivotal tasks of faculty development.

\section{Equipped to be story tellers for a new generation?}

Norman E. Wagner a retired president of the University of Calgary, published a deceptively simple book with the title From chaos to wisdom: A framework for understanding (1998). In this book he argues that information can only become knowledge when it is placed in a context, and when that context is elaborated to the extent that it becomes a world view, a personal frame of reference (Wagner, 1998:82). The accomplishment of such an integrated view, he says, comes about by narratives. He states: "The pilgrimage of 
the people of faith is built on the challenge of going from information to knowledge via narrative. The practice of retelling the story is at the heart of Judeo-Christian tradition." This emphasis on story telling as the essence of the task of the teacher is a common refrain in most disciplines today. It is also a very clear part of the Biblical revelation about the way a younger generation is initiated into the ways of the covenant. Psalm 78 speaks about one generation passing on the message to another about the "great deeds of God" (Seerveld, 2000). The telling of these stories in a Biblical context have to do with the generation of faith in those who hear the story, so that they in turn are able to tell the story of God's faithfulness to the next generation. When it comes to academic lecturers and teachers the focus of the narratives they tell about Gods faithfulness in the class room is from a theoretical angle, but ultimately they too are pointing to the great deeds of God. The search that Wagner portrays has everything to do with the struggle of the people of God to come to grips with the texts or words they long to accept as authoritative texts (stories or narratives) in and for their lives authoritative texts upon which they can build their lives. In my opinion this approach would be the valuable objective we want to achieve - the personal appropriation by students or the indwelling in the story of God's faithful acts in His world that permeates a personality in such a way that even if the title of the text book or course be forgotten, the class notes be lost, the name of the course or professor be forgotten, the deeply embedded insight into the miracles of God's multifaceted involvement with His world, with nature, culture, creation and His image - humankind - will indelibly be etched in the personality and sensibilities of young people. The key word in this respect is the personal appropriation of a way of looking at the world which will lead to a way of living characterised by integrity, wholeness or the Biblical word shalom. It is also a world view that ought to give rise to a restorative, redemptive and healing way of life (Walsh,1994:28). Christian education is a significant dimension of this way of life.

\section{Christian education}

Christian education is the transmitting of such a horizon of "things that matter ..." forming the backdrop to a distinctively Christian world view, lifestyle and way of thinking about the world. This point of departure implies encouraging what Fernhout (1997:95) calls the responsibility of Christians to give specific expression "... to their indwelling of the gospel story" in education. Fernhout argues that his choice for a metaphor of education as cultural story telling is a 
response to Wolterstorff's call for a new model for the curriculum. Where Wolterstorff concentrated on the metaphor of "shalom community" as model for the renewal of the curriculum, Fernhout chooses cultural story telling which he argues does not only entail the vision component of Christian education but also the content of that vision. Both Fernhout (1997), Bolt (1993) and others emphasise this "narrative" character of education. There seems to be a resurgence of interest in "narrative" and the role it plays in various dimensions of human life. The reasons for this particular emphasis may vary, but the emphasis on stories as an alternative way of imparting knowledge especially at the elementary level of education, appears to be worth consideration. Why? Because stories embody more than only ideas, encompass more than only rational and universal knowledge, are based on full, concrete human experience. Stories represent more fully the processes and patterns through which human beings interpret the world they live in and give meaning to events and actions and represent a more holistic approach to knowledge and knowledge transfer. This function of stories implies the transfer of a Christian body of knowledge which forms the basis of the Christian mind and Christian view of life and the world, but it entails more than only intellectual equipment of young people. It requires spiritual development and formation of the whole person that will result in a way of life that is obedient to God in all dimensions of life. As Wolterstorff (1984) indicates, education thus implies modelling, discipline and giving reasons for what is the case. This kind of education requires that Christian educators challenge public policies that are contrary to this story and develop curricula and teaching practices that reflect the implications of an integral view of humanity, the world and society.

What is it in our world view that constitutes such a way of life? I believe it is a sense of knowing there is something deeper to life than that which is obvious - it is the ability to see beyond the obvious. Such a world view implies the certain knowledge that what we have come to know about life, history, culture, human relationships are deeply embedded and ingrained in the hidden treasure of God's merciful and providential care and His Word for His world. It is the deep and secure certainty that our lives are ultimately related to this quest - the deeper quest - the coming of His Kingdom. University teachers and researchers are mature and "developed" when this sense permeates their lives, teaching and work. We have achieved faculty development worthy of the qualification of "discipling: when we have succeeded in convincing a new generation that seeking this wisdom is what life is all about. And 
this wisdom should enable us to discern the deep contours of the struggle between God and Satan in ourselves, the world around us, the young that we teach and the subject matter that we are involved in. This discernment can be established because in final instance the knowledge imparted and the knowledge acquired participate in a historical struggle to which God's people are called - the struggle to bring light into the darkness, healing to the broken and consolation to those who are suffering. Without this depth dimension of the acquisition and purpose of knowledge, a degree certificate only certifies a couple of years spent somewhere under the tutelage of people in turn equipped with similar certificates.

The deeper quest though is to have introduced both teachers and students to the ever present signs of the active and very present providential care of God our Creator in His world. The deeper quest is having handed them the "key" to the hidden treasure, the Word of God, having provided them with the map to discover this treasure. I seem to be running out of images here - my concern, however, is whether we have acquired the deeper restless urge to want to find the silver of God's Word, whether the younger generation will under the guidance of university profesors and teachers be willing to sacrifice deeply for what they fundamentally believe is valuable.

\section{The hidden treasure}

Speaking about the hidden treasure implies whether and how we actually succeed in the deeper quest, the quest to discover the hidden "silver" - the wisdom that Scripture refers to in Proverbs. The whether and the how relate to extremely important questions. They relate to the core of what we think we are attempting to achieve at a Christian Liberal Arts college and a Christian university. What were all these narratives about in final instance? Were they the stuff out of which eventually many more books were made or were they related to the deeper quest - the quest Scripture speaks about in the passage in Proverbs 2? The courses we teach and the programmes we develop are narratives about how to find some dimension of the "hidden treasure" spoken of in this text - the Biblical metaphor or image for wisdom. Well, that is what the narratives ought to have been about. It is possible that these stories contained data, facts, statistics, information - even perhaps some nuggets of knowledge. But they were only valid clues to the hidden treasure if they also contained wisdom, showed the way to wisdom and guided young people on the road to wisdom. How would one know whether this was actually accomplished, that it is really the case? I think the image of the hidden treasure or the silver in 
Proverbs 2:1-5 which speaks of "understanding the fear of the Lord and finding the knowledge of God" provides a clue. This formulation has to do with the wisdom God provides - the wisdom shielding those who walk with integrity, guarding the paths of justice and leading to the understanding of righteousness and justice. In an academic setting integrity or wholeness acquires its own unique profile as it is gradually shaped, refined and polished by the interaction with peers, fellow academic teachers and the subject matter. Christian education, on the other hand ought to be in the business of excavating, purifying, refining true authenticity. Authenticity not only implies intellectual authenticity but also the integrity of the self. Integrity means being "together", being whole, having experienced healing ... redemption. It is this same redemption that we are called to bring about in the world around us.

The proclamation of the Lordship of Jesus Christ comes to expression in various dimensions in the life of a Christian. Or, formulated differently, our witness as the new "rainbow people" as Nelson Mandela formulated it in a different context - a new people of God - is a multifaceted witness. It is a multi-coloured ministry in which our apologetic task acquires the contours or the colour of the dimension of life in which we are called to live and to be witnesses. As such one could say there is a plurality of callings to witness and manifold ways in which to proclaim the Lordship of Jesus Christ in our personal and communal lives. In the midst of this differentiation of possible callings a dynamic centre or core of our human existence is discernible - a core that pertains to our most fundamental, central relationship - the relationship to the risen Lord which directs and ought to permeate all these diverse ways of serving God.

\section{List of references}

BOLT, J. 1993. The Christian story and the Christian school. Grand Rapids: Christian Schools International.

CALVIN COLLEGE. 1970. Christian Liberal Arts education: Report of the Calvin College Curriculum Study Committee. Grand Rapids: Eerdmans (CLAE).

CALVIN COLLEGE. 1997. Core curriculum review document: Engagement in God's world: A statement of purpose for the core curriculum of Calvin College. Grand Rapids: Calvin College.

FERNHOUT, H. 1997. Christian schooling: Telling a world view story. (In Lambert, I., Mitchell, S., eds. The crumbling walls of certainty. Sydney: Centre for the Study of Australian Christianity. p. 75-98.)

MOUW, R. 1987. Knowing and doing. (In Carpenter, J.A. \& Shipps, K.W., eds. Making higher education Christian: The history and mission of Evangelical Colleges in America. Grand Rapids: Eerdmans/Christian University Press. p. 217-230.) 
PALMER, P. 1998. The courage to teach: Exploring the inner landscape of a teacher's life. San Francisco: Jossey Bass.

PIPPERT, R.M. 1979. Out of the saltshaker into the world. Downer;s Grove: InterVarsity.

SEERVELD, C. 2000. A cloud of witnesses and a new generation. (In Bartholomew, C., ed. In the fields of the Lord: A Calvin Seerveld reader. Carlisle: Piquant. p. 209-234.)

VAN BRUMMELEN, H.W. 1986. Telling the next generation: Educational development in North American Calvinist Christian schools. Lanham: University Press of America.

VAN BRUMMELEN, H.W. 1988. Walking with God in the classroom: Christian approaches to learning and teaching. Burlington: Welch.

WAGNER, N. 1998. From chaos to wisdom: A framework for understanding. Calgary: Knowledge-at-work.

WALSH, B.J. 1994. Subversive Christianity: Imaging God in a dangerous time. Seattle: Alta Vista College Press.

WOLTERS, A.M. 1985. Creation regained: Biblical basics for a Reformational world view. Grand Rapids: Eerdmans.

WOLTERSTORFF, N. 1984. Reason within the bounds of religion. Grand Rapids: Eerdmans.

WOLTERSTORFF, N. 1987. Teaching for justice. (In Carpenter, J.A. \& Shipps, K.W., eds. Making higher education Christian: The history and mission of Evangelical colleges in America. Grand Rapids: Eerdmans/Christian University Press. p. 201-216.)

WOLTERSTORFF, N. 1989. Keeping faith: Talks for new faculty at Calvin College. (Occasional papers from Calvin College, 7(1), February.)

YANCEY, P. 2000. Reaching for the invisible God: What can we expect to find? Grand Rapids: Zondervan.

\section{Key concepts:}

Christian scholarship

faculty development at tertiary level

integrality of faith and learning

world view

\section{Kernbegrippe:}

Christelike wetenskap

integrasie van geloof en wetenskap

lewens- en wêreldbeskouing

personeelontwikkeling op tersiêre vlak 